\title{
Leading transformation in a family-owned business: insights from an italian company
}

Filomena Canterino, Department of Management, Economics and Industrial Engineering,

Politecnico di Milano

Stefano Cirella, Department of Management, Economics and Industrial Engineering, Politecnico di Milano,

Marco Guerci, Department of Management, Economics and Industrial Engineering, Politecnico di Milano,

Abraham B. (Rami) Shani, Orfalea College of Business, California Polytechnic State University, Massimo Brunelli

Article published in International Journal of Entrepreunership and Innovation Management

Please cite as: Canterino, F., Cirella, S., Guerci, M., Shani, A. B., \& Brunelli, M. S. (2013). Leading transformation in a family-owned business: insights from an Italian company. International Journal of Entrepreneurship and Innovation Management, 17(1/2/3), 54-83. 


\title{
Leading transformation in a family-owned business: insights from an italian company
}

\begin{abstract}
The increasing volatility of the global economy, coupled with the pace of technological innovation, presents new challenges for family-owned businesses. The complex business dynamics and business inertia of family-owned business require a comprehensive perspective when developing the capability to manage transformations in the face of a business context such as this. This article draws on literature from the field of organisational change and development, organisational behaviour and family business, and proposes an integrative framework. The study is embedded in a collaborative research project with an Italian fashion design company, and portrays a five-year transformation process, starting with the family's decision to hire an external CEO for the first time in its hundred-year history. What has been learned from the case serves as the foundation for a further advancement of the proposed process-model for the management of a transformation in a family-owned business. The implications for research and practice are discussed.
\end{abstract}

Keywords: transformation; organisational change; transformational leadership; organisational behaviour; family firm; family business; Italy.

\section{Introduction}

The increasing challenges of global competition and rapid changes in technology and markets have created the necessity to develop organisational transformation capabilities (Beer, 2009). Studies across industries and time periods have identified the difficulties involved in implementing transformations successfully, and highlighted the crucial role that leadership practices play in successful transformations (Collins, 2001; Collins and Hansen, 2011; Kotter, 1995). Thus, exploring different ways to design, manage and lead transformations is likely to result in a deeper level of understanding and improve managerial actions.

Building transformation capabilities in family businesses, which are a critical engine of the economic fabric in every community, region, country and continent, is complex. The notion of 'familiness' - viewed as the interweaving of business and family relationships (Habbershon et al., 
2003) - creates unique and intriguing organisational characteristics and dynamics. Indeed, despite the increased scientific focus on family businesses, relatively little is known about leading and managing complex transformations and transformation capabilities in family-owned businesses (Cassia et al., 2012). The process of overcoming an economic crisis suggests that helping family-owned businesses build a capacity for continuous transformation is of the utmost importance (Schulze et al., 2001).

The focus of this paper is on leading transformation in family-owned businesses. A transformation is defined as a radical shift in the value, culture, structure, and routines, and the 'how to do business' aspect of an organisational system. The aim of this paper is, therefore, to identify the complexities of leading transformations such as these within a family business. Its main contribution is to suggest an integrative managerial framework that might be used by managers of family businesses in leading transformations, and to offer a holistic guided view of the phenomenon and its complexities. The proposed framework is then utilised for an examination of the transformation of an Italian fashion design company.

This article consists of four sections. In the first, we review and summarise the literature on the three basic elements of the theoretical framework, drawing on three management research streams, namely:

1 organisational change and development, for presenting the concept of transformation

2 organisational behaviour, for discussing the relevance of leading in transformation

3 family businesses, for illustrating the key features of these entities.

Next, we put forward a framework that identifies the strategies and phases which are critical for designing and managing the transformation of family businesses, drawing theoretical principles from the research streams we have reviewed previously. Section 2 of this paper is a case study on an Italian fashion design company to which we apply our proposed framework; the study highlights both the process of transformation and its complexities. A discussion that draws attention to the challenges 
encountered in the transformation of family-owned business follows, based on the case study. The final part summarises what has been learned, presents the study's contribution to family business practices, and discusses the implications for research into family businesses from an integrative perspective.

\section{Theoretical foundation: towards a framework for understanding family-owned businesses and their transformation}

The framework proposed in this paper is driven by the integration of elements from three distinct bodies of scientific knowledge: organisational theory and design, with an emphasis on the emerging key features of family-owned businesses; organisational behaviour, with an emphasis on transformational leadership; and organisational development and change, with an emphasis on transformations and the transformation process. In the following subsections, we will review the literature on family-owned businesses and transformation. The proposed framework will then be presented and briefly described.

Family-owned businesses: key features

Family businesses are essential to the livelihood of $85 \%$ of the world's private sector employees (Poza, 2008), but, although the importance of family businesses in today's economy is clear (Schulze et al., 2001), little attention has been paid to family-owned businesses in the mainstream organisational and management studies literature (Cassia et al., 2012). This gap is problematic, as the global economy is struggling, and the pressures for redesign and change are mounting. The volatility of the global economy, coupled with fast-paced technological advancement, suggests that the development of new capabilities and change capabilities are critical for the survival of family-owned businesses. For this type of enterprise, transformation and the development of transformation capabilities are not an option but a necessity (Shani et al., 2012) in order to be able to respond to rapidly changing customer demands without compromising technological excellence and quality (Verganti, 1999). This is a complex task 
for family businesses, and requires the development of a variety of organisational learning mechanisms (Fredberg et al., 2011), and the creation of an ongoing organizational dialogue and transformation orientation (Beer, 2011).

Family businesses have many features that are common to all enterprises, but the combination of business and family relationships leads to specific organizational characteristics and dynamics (Cater and Schwab, 2008). The literature confirms that family businesses are generally different from non-family enterprises in the way they operate, mainly due to the presence of a specific family founder spirit, family tradition, family vision, goals, and values that determine their key general characteristics (Cassia et al., 2012; Cater and Schwab, 2008). These characteristics flow into the concept of ‘familiness’ (Habbershon et al., 2003).

Organisational and management studies have generated a variety of conceptual models and theories to capture the essence of organisations. This paper follows the basic model advanced by Galbraith (2002), or what has become the 'star model' of organisations. At a very basic level, Galbraith argues that different strategies require different organisations, that organisations consist of business and management processes, rewards systems, and people practices in addition to structure, and that an effective firm is one that aligns all of the elements of the star model. A summary of the key features of a family business that can be found in the literature is set out in Galbraith's (2002) theoretical framework of organisations (see Table 1).

Table 1. Key characteristics of family-owned businesses

\begin{tabular}{|l|l|l|}
\hline $\begin{array}{l}\text { Design elements of an } \\
\text { organization (adapted } \\
\text { from Galbraith, 2002) }\end{array}$ & $\begin{array}{l}\text { Key differentiating features } \\
\text { based on the previous } \\
\text { literature on family } \\
\text { businesses }\end{array}$ & $\begin{array}{l}\text { Key findings at family businesses based on the } \\
\text { empirically published literature on family } \\
\text { businesses }\end{array}$ \\
\hline Strategy & 1 Mission and values & $\begin{array}{l}\text { 1. Shared goals and values based on the family } \\
\text { founder spirit, family tradition and a long-term } \\
\text { orientation that influence strategic direction and } \\
\text { process (Poza, 2008; Zellweger, 2007; Sharma } \\
\text { et al., 2003) }\end{array}$ \\
\hline
\end{tabular}




\begin{tabular}{|c|c|c|}
\hline & 2. Strategy orientation & $\begin{array}{l}\text { 2. A conservative, risk averse strategy, with } \\
\text { limited exporting and internationalization } \\
\text { (Dunn, 1996) and a preference for staying } \\
\text { within specific and known market niches (Poza, } \\
\text { 2008) }\end{array}$ \\
\hline \multirow[t]{2}{*}{ Structure } & 1. Management system & $\begin{array}{l}\text { 1. Less emphasis on formal structures, } \\
\text { coordination, and monitoring systems (Cater } \\
\text { and Schwab, 2008), and preference for placing } \\
\text { family members in charge (Birley, 2002) }\end{array}$ \\
\hline & $\begin{array}{l}\text { 2. Horizontal/vertical } \\
\text { linkages }\end{array}$ & 2. More inward vertical linkages (Dunn, 1996) \\
\hline \multirow[t]{6}{*}{ Processes } & $\begin{array}{l}\text { 1. Decision-making } \\
\text { processes }\end{array}$ & $\begin{array}{l}\text { 1. More emphasis on intuitive decision-making } \\
\text { and less on a rational decision-making } \\
\text { processes (Filbeck and Smith, 1997) }\end{array}$ \\
\hline & $\begin{array}{l}\text { 2. Accountability and } \\
\text { control processes }\end{array}$ & $\begin{array}{l}\text { 2. More emphasis on informal accountability and } \\
\text { control processes (MacKenzie, 2002; Morris et } \\
\text { al. 1997) }\end{array}$ \\
\hline & $\begin{array}{l}\text { 3. Communication } \\
\text { processes }\end{array}$ & $\begin{array}{l}\text { 3. More emphasis on informal communication } \\
\text { processes and less on formal communication } \\
\text { (Cater and Schwab, 2008) }\end{array}$ \\
\hline & $\begin{array}{l}\text { 4. Creativity and innovation } \\
\text { processes }\end{array}$ & $\begin{array}{l}\text { 4. Limited emphasis on creativity and innovation } \\
\text { (Cirella and Shani, 2012) }\end{array}$ \\
\hline & 5. Change processes & $\begin{array}{l}\text { 5. Focused orientation on growth and development } \\
\text { (Jensen, 2003); change viewed as a potential } \\
\text { threat to the family tradition, enterprise history, } \\
\text { and identity (Dyer, 2003; Poza et al., 1998); } \\
\text { different degrees of risk taking, depending on } \\
\text { the characteristics of the generation in control } \\
\text { (Miller et al., 2003) }\end{array}$ \\
\hline & $\begin{array}{l}\text { 6. Information and } \\
\text { Communication } \\
\text { Technology processes }\end{array}$ & $\begin{array}{l}\text { 6. Continuous need for major financial } \\
\text { investments and commitment (Cater and } \\
\text { Schwab, 2008) }\end{array}$ \\
\hline Rewards & $\begin{array}{l}\text { 1. Procedures related to pay } \\
\text { and career }\end{array}$ & $\begin{array}{l}\text { 1. Altruistic tendency of the family towards non- } \\
\text { family employee compensation (Schultz et al., } \\
\text { 2003; Gersick et al., 1997) to raise high family } \\
\text { visibility and reputation with the employees and } \\
\text { community as a whole (Dunn, 1996) }\end{array}$ \\
\hline \multirow[t]{2}{*}{ People } & $\begin{array}{l}\text { 1. Degree of } \\
\text { professionalism in HRM } \\
\text { practices }\end{array}$ & $\begin{array}{l}\text { 1. Less progressive in terms of human resource } \\
\text { issues (for example, employee involvement, } \\
\text { proper staffing) and tendency for over-staffing } \\
\text { (Donckels and Frolich, 1991) }\end{array}$ \\
\hline & $\begin{array}{l}\text { 2. Member's attributes and } \\
\text { needs }\end{array}$ & $\begin{array}{l}\text { 2. Latent conflicts due to the dynamic interface } \\
\text { between family and non-family members } \\
\text { (Cassia et al., 2012); higher motivation, }\end{array}$ \\
\hline
\end{tabular}




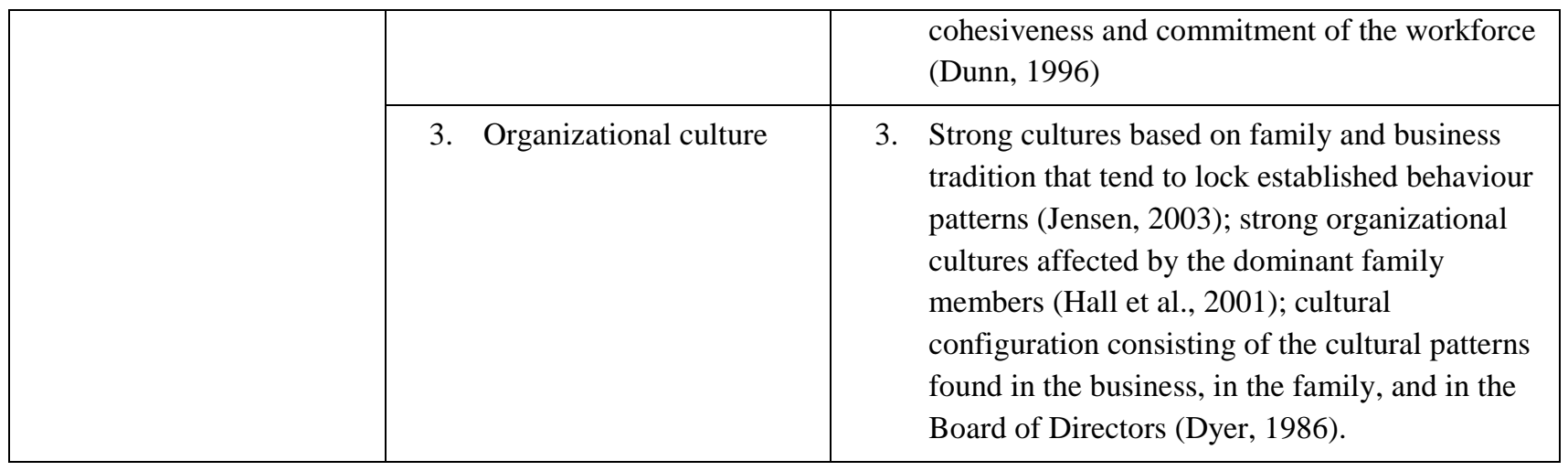

The complex mixture of family and professional relationships (Cassia et al., 2012) creates the unique characteristics of family businesses. For the purposes of this paper, these can be summarised in three key elements. The literature seems to agree that the general orientation of family businesses appears to be more long-term (Poza, 2008; Zellweger, 2007; Sharma et al., 2003); this could be risky in turbulent contexts, but it is also a notable quality that can prevent managerial myopia and tensions towards short-term results, which are not beneficial to the prosperity of a firm (Le Breton-Miller and Miller, 2006). At the same time, traditions, risk adversity, strong mental models and strong organisational cultures affected by the values of dominant family members lead to a general culture that nurtures inertia (Dunn, 1996; Jensen, 2003; Hall et al., 2001). As Dyer (1986) suggests, the culture of a family enterprise should be viewed as a configuration of the cultural patterns found in the business, in the family, and in the board of directors. Finally, family businesses tend to place less emphasis on ongoing innovation and creativity, which translates into under-utilisation of capabilities and missed opportunities for growth and development (Dyer, 2003; Poza et al., 1998), even though there is a part of the literature which says that family firms are more inclined to be risk takers. This aspect seems to depend on the characteristics of the family members in charge (Miller et al., 2003), and on the propensity to foster entrepreneurial change (Hall et al., 2001). One of the possible cumulative effects of the family dynamics is that business inertia can easily settle in Poza (2008), and leaders shoulder the responsibility for addressing the challenges posed by inertia (Battilana et al., 
2010). The transformational process is one in which transformational leaders influence followers in such a way that the firm can achieve a level of performance that will allow it to succeed (Bass, 1998; Bass and Avolio, 1990).

\section{Transformation and Transforming Organizations}

By its very nature, the term 'change' has different meanings and dimensions: a variety of typologies and clustering of different types of change in a system have been proposed in the literature (for example, Shani and Stjernberg, 1995; Ackerman, 1986; Jick, 1992). At a more basic level, change tends to be more radical and implies a transformation:transformation entails a radical shift in the value, culture, structure, and routines of an organisation, and - holistically speaking - how to do business (Beer, 2009). Among the various labels (such as organisational transformation, corporate transformation, and system-wide transformation), transformation is always an all-pervading, holistic, and extended process (Mitki et al., 2008). It may be one that has been thought out in detail from the outset, but more probably it goes ahead or emerges depending on the impact of earlier measures taken or on developments in the organisation and its context. The complexity of the system being transformed and that of the transformation process itself are key features of transformation processes. Transformation is an integral part of any living system. As Bartunek and Louis (1988), and Beckhard (2006) have pointed out, transformation raises a major set of challenges for any system. The focus on creating sustainable work systems in the context of global economic turbulence adds an additional layer of complexity to the transformation of any social system. It is often argued that the complexity of the contextual environment seems to be growing in magnitude and intensity. A rich diversity of theories have been developed in an attempt to understand and explain the multiple aspects of system transformation, and its context, complexity, content, processes, and outcomes (Bradford and Burke, 2005; French et al., 2005; Gallos, 2006). 
Transformation can be triggered by a variety of events that occur in the contextual mess of the system. Ackoff (1981) coined the term 'contextual mess' to describe the increasing complexity of the business environment. Contextual mess sets in motion the forces and events that precipitate alternative managerial thinking, managerial action, and new types of behaviour. Managers need to focus on the study of these triggering events and their impact as possible new windows of opportunity for company sustainability and future growth and development. An event is viewed as a triggering event if, due to its magnitude and potential system impact, it sets in motion a series of mental shifts as individuals seek to understand and redefine the situation (Nadler, 1998). Triggering events challenge current thinking, practices, and routines, evoke conscious thought on the part of the members of the system, and create a dynamic that leads the mind-set of members of the organisation into the arena of transformation.

The number of studies examining the dynamics of transformations of systems continues to increase. This growth is driven by the need for the system to change if it is to survive. The transformation process requires the system to utilise most of its resources in an optimal way. If the system is to try to develop a radical re-conceptualisation of its vision, mission, culture, strategy, structure, work design, leadership, and the like, careful attention to the learning process is likely to be of great help (Senge, 1999). Understanding the contextual mess and the triggering events, their potential impact on the system, and the possible opportunities they create, and determining what kind of change is required is a challenge for any system. The capacity to learn (and at times to learn rapidly) is crucial for the transformation of a system (Argyris and Schon, 1996; Boud et al., 2006). Given the contextual mess and the triggering events, CEOs and leaders face the basic challenge of managing transformation processes (Nadler, 1998).

The nature and complexity of transformation seems to run-counter to the essence of most family-owned business and their culture and dynamics. The literature suggests that family business 
members tend to be private and secretive, and conflict avoiders, and that they are seldom willing to examine or reflect on current processes and practices (Poza, 2008). These aspects cannot be ignored when considering transformation processes in family businesses. Cater and Schwab (2008), for example, hypothesised that different elements of 'familiness' - for example, strong family ties to the business and among the top managers, a preference for putting family members in charge, consensus orientation, and more informal management systems - can reduce the ability of an established family business to initiate transformations, such as changes in the top management. On the other hand, other elements of 'familiness' such as long-term orientation and altruistic behavioural tendencies can increase the ability to implement transformations, as in the case of retrenchment in response to a crisis (Cater and Schwab, 2008; Zahra, 2003). Pinto and Couto-de-Souza (2009) use an illustrative case of a failed transformation in a Brazilian family business in the healthcare sector to underline the general difficulty of developing successful transformations for family businesses. Salvato et al. (2010) use a case study to suggest that the inhibitors of transformation in family-controlled organisations can be turned into facilitators of transformation, such as shifting from being anchored in past performance to aspirations for future performance, and turning past-anchored orientation into future-focused impetus. Behind these assumptions about the moderating role of 'familiness' characteristics, the nature of transformational processes at family businesses remains an unexplored research area and represents a promising direction for investigation.

\section{Transformational Leadership}

Leading transformation in a family business requires a transformational leadership perspective orientation and skill set. Transformational leadership focuses on changing members' attitudes in order to achieve increased commitment to the transformation objectives. Transformational leaders motivate followers by making them more aware of the importance of task outcomes, and by inducing them to 
transcend their own self-interest for the sake of the organisation (Yukl, 1994). Thus, a transformational leader is one who enhances the motivation, morale, and performance of followers through a variety of mechanisms (Bass and Avolio, 1990). The literature on leadership suggests that transformational leadership has much in common with charismatic leadership, and that charismatic leadership is only a part of transformational leadership (Bass and Riggio, 2006). Transformational leaders tend to be engaged on many levels, with different business and social units and around a wide spectrum of business issues. Few studies have attempted to identify the key features of transformational leadership. For example, the four components of transformational leadership identified by Avolio et al. (1999) include idealised influence (transformational leaders behave in ways that enable them to serve as role models for their followers; they are admired, respected, and trusted; they emphasise the importance of having a collective sense of mission, and reassure others that obstacles will be overcome), inspirational motivation (transformational leaders behave in ways that motivate and inspire those around them by providing meaning, and challenge their followers' work and performance), intellectual stimulation (transformational leaders provide stimulation for their followers to be creative and innovative by questioning assumptions and reframing problems in new ways), and individual consideration (transformational leaders tend to focus and address followers' needs for achievement and growth by acting as mentors and coaches). Four further components of transformational leadership identified by Bennis and Nanus (1985) include a Vision of the organisation's future (which should be clear, compelling, believable, and attractive), a social architecture capability (to shape the shared meanings maintained by individuals in organisations, and set a direction for subordinates to share the new organisational identity), trust creation among followers (based on setting and consistently implementing a direction), creative deployment of self through positive selfregard (transformational leaders have to focus on their strengths and not on their weaknesses, to create feelings of confidence and positive expectations in their followers). This complex bundle of 
compelling competencies can be achieved in different forms; according to Ford and Ford (2012), and Gronn (2002), these include focused leadership, in which only one person is attributed the status of leader, and the unit of analysis is the stand-alone leader and his or her behaviours, activities and style; collective distributed leadership, when leadership is divided among a group of organisation members who neither operate in concert nor collaborate; and co-performing distributed leadership, which assumes concerted action by a specific group or unit of people.

The complex nature of family business transformation suggests that there is a pivotal need for the ability to take such an endeavour forward. Having the appropriate leaders and leadership orientation to lead this type of effort is likely to increase its chances of success. Transformational leaders are likely to be critical ingredients, as they have the necessary knowledge base and skills. As such, they are likely to be a key element in the transformation process.

We now present a comprehensive framework for understanding and guiding family-owned business transformations.

\section{Leading Transformation in Family Businesses: A Proposed Guiding Framework}

Building on Beckhard and Pritchard's (1992) three states of change, namely the current state, the transition state and the desired state, Poza's (2008) organisational development change model in family companies, and Greiner et al.’s (2003) transformation model phases, we suggest an integrative guiding framework for leading transformation in family businesses (Figure 1). The main objective of the framework is to propose a guiding, holistic view of the phenomenon and its complexities. 
Figure 1. A guiding framework for leading transformation in family business

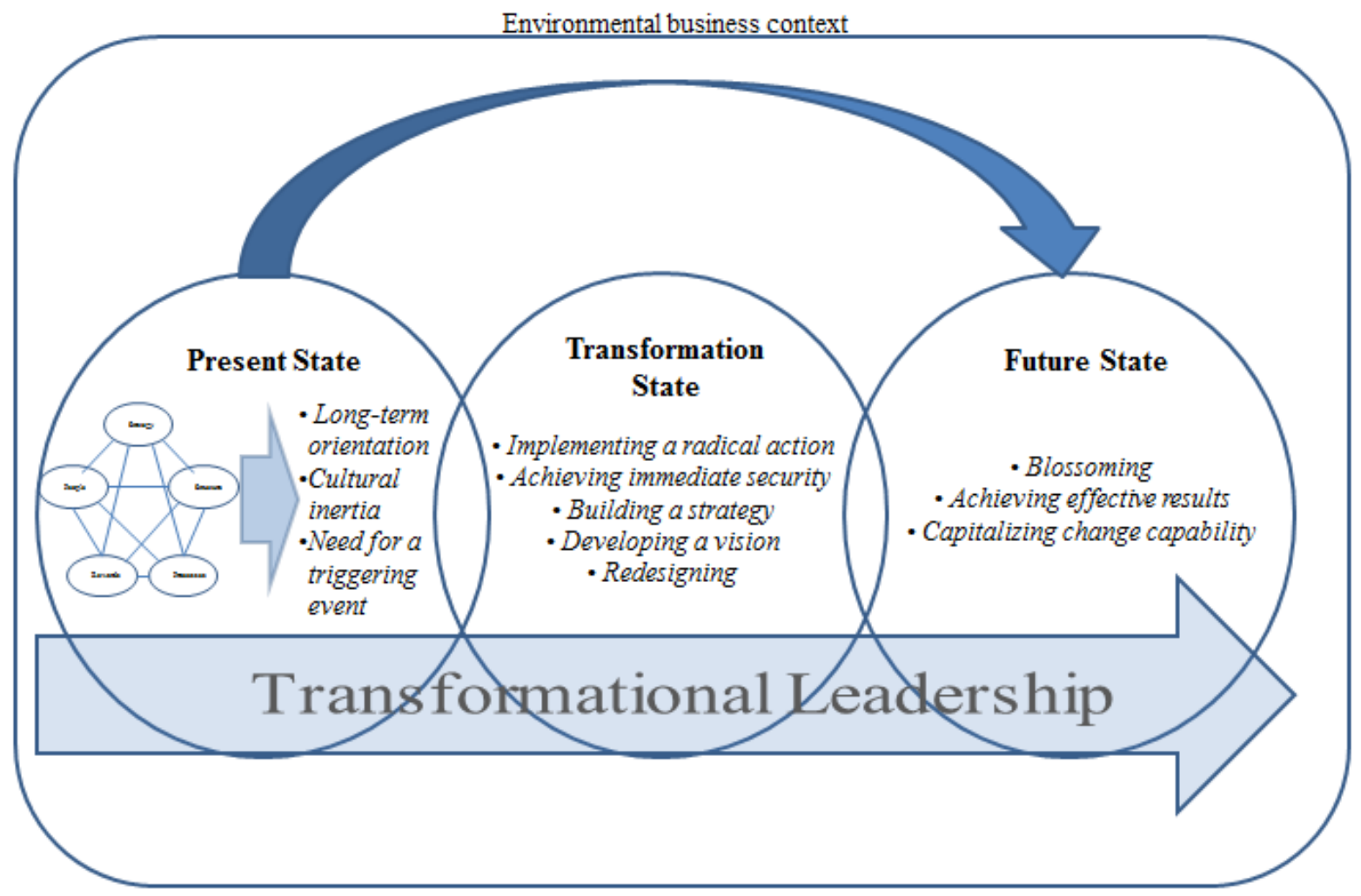

The framework is composed of three main elements: namely, the present state, the transformation state - made up of five phases - and the future state. The overall transformation is led and supported transversally by a transformational leadership. The framework captures the dynamic nature of the relationships among the three main elements, and provides a close-up on the complex interplay between the transformation process and the richness of the 'familiness' characteristics.

Present State. In order to drive the company from its present state into its transformation state, and then into its future state, it is essential to identify, understand, and overcome the key elements of the present state (Poza, 2008). Based on a mapping of the family business profile (using the Galbraith Five Star model), the nature of three key elements - the long-term orientation of the firm, cultural inertia, and the need for a triggering event to find the road to transformation - is examined. These key elements are derived from the distinctive characteristics of family businesses, as illustrated in Table 
1, and in particular from family dynamics and the family's goals and values (Cassia et al., 2012), strong cultures, a narrowly-focused orientation to creativity and innovation (Jensen, 2003; Cirella and Shani, 2012), and the possible tendency to be less oriented to growth and more resistant to change, which is viewed as a potential threat to family traditions and identities (Dyer, 2003).

Transformation State. This state represents the process of transformation, and consists of five phases. The transformation state represents an integrative attempt to identify the phases of transformation (Greiner et al., 2003) and captures the complexities of transformation in a family business (see Figure 1). The five phases are:

1 Implementing radical action: this phase includes the definition of a mandate for change, negotiation among all the stakeholders, and a focus on the immediate priorities in responding to the triggering event.

2 Achieving immediate security: this phase aims at achieving an early positive impact. In many cases, the focus is on actions related to attaining financial security. One common mistake is to start developing a long-term vision too early. This phase adds credibility to the transformation, and increases its probability of success.

3 Building a strategy: the aim of this phase is to build the long-term vision of the transformation with the development of a strategic direction for the firm.

4 Developing a vision: this phase includes the definition of a competitive logic that explains how the company intends to use its internal strengths to enhance its market position (vision). 5 Redesigning: in this phase, a massive effort is undertaken to redesign or realign the company structure and its processes.

Future State. The future state is a composite of the transformation outcomes, and is equivalent to mapping out and effectively achieving the results expected (Poza, 2008). Blossoming aims to release and mobilise the transformation energy, and consolidate and follow the decisions and actions of the 
transformation. At this stage, the company has also built a capacity for continuous learning. This requires sufficient energy, capability and confidence to be deeply instilled in the organisation so that all the members see themselves as activists responsible for carrying out change every day (Greiner et al., 2003).

The proposed framework is comprehensive, with the intended objective to integrate bits and pieces of diverse and relevant literatures. The framework underlines the complex dynamics that exist within and among the different elements, and suggests the need for further exploration.

In what follows, we provide an illustrative case study on an Italian family business, a fashion design company that has gone through a complex and systemic transformation. The framework suggested in this paper is utilised in order to examine the transformation process.

\section{Illustrative case: an Italian family business of fashion design}

A multi-phased collaborative research study involving one of the top companies in the Italian fashion design industry provided the data for the case analysis and illustration that follows. The company is a family-owned business that designs and produces silk accessories for men and women, such as scarves, ties and women's wear. The aim of the study was to explore the nature of an ongoing transformation in a family-owned business.

\section{Methodology}

The illustrative case is based on a long-term collaborative management research project (Cirella et al., 2012). This case analysis exploits an opportunity to explore a significant phenomenon under rare or extreme circumstances (Yin, 1989). The case selection was purposive. We searched for an organisation that:

a was family-owned, with a long history and a strong family tradition

b had experienced an organisational transformation. 
We approached a family company that was among the top five designers of premium silk products for high-end fashion labels, and which was striving for a complex transformation. The process included semi-structured interviews, based on specific interview protocols. The interview protocols included questions about the family business (its markets, products, strategy, structure, processes, challenges, and plans for the future), and specific questions intended to map the transformation process that the company had embarked on. The interviewees were the CEO who led the transformation, the top managers of the company, and a few family members. Particularly, three in-depth interviews with the CEO took place at different moments of the transformational process. All the interviews were faceto-face, were conducted in Italian, and lasted about one hour (two hours in the case of the CEO interviews). They were all carried out by at least two researchers who had the task of conducting interviews. The interviews were all taped and transcribed. Data were analysed on a set of default variables: key activities, actors, barriers, and results. Each transcribed interview was read, coded, and analysed by two researchers in a series of meetings, re-readings and re-coding. On completion of the analysis, external readers with knowledge and experience of the topic also reviewed the data in order to assure interpretation validity. For the purposes of this paper, some of the data from the total set of data collected was extrapolated, with the objective of illustrating the transformation, and the quotes were translated into English. We will start by providing a brief description of the Como textiles district, which is the geographical context of the case. Given its relevance, we also present the background of the family and family business.

\section{The Como textiles district}

The Como textiles district is located in Northern Italy, at the border with Switzerland. This was fertile ground for the industrial revolution of the second half of the nineteenth century. Creative design, product quality, flexibility in adapting to changing customer needs, a high level of service (in terms of execution and delivery as well as customisation of production) and productivity through process 
technology have been the drivers of the district's success since that time. These technologies are the main field of innovation in the sector.

According to Gilodi (2011), there are approximately 550 local firms specialising in the transformation of silk and artificial textile yarns into fabrics, and in packaging for clothing, involving about 14,500 workers (approximately 30\% of the manufacturing manpower of the entire area).The district is dominated by small companies with a low turnover, generally specialising in a single phase of the transformation process of silk or the many weave yarns into fabrics, and packaging materials for clothing and furnishings. There is also a huge number of commercial enterprises (called 'converters') which play an important role in coordinating the various stages of production. The majority of the firms in the district are family enterprises. The composition of the district in terms of vertical integration is very heterogeneous, and all the textile firms in the area can be classified into four categories: diversified and vertically integrated medium-large companies; small contractors characterised by a high degree of specialisation, and focused on specific phases of treatment; integrated mono-business companies; and 'converters', which focus on commercial functions, and play an important role in coordination of the various phases of production and maintaining contacts with the market.

The high quality level of the products is partially due to the fact that the configuration of the district, which is characterised by geographical concentration and proximity, makes it possible to achieve an ongoing flow of competences which permits development of know-how with a specific high qualitative content which is hard to emulate from outside. Finally, it should be emphasised that the textiles industry has been going through a period of massive restructuring over the past ten years due to the global economic crisis and increased global competition. 
The Family and the Family Business: Soft Silk

Located in the Como textile district, Soft Silk (a fictitious name to preserve the company’s anonymity) was founded in 1902, and today operates in the Italian, US, French, and Chinese markets, covering the premium market segment for silk products. Its clients include the best-known players in the fashion industry. The district context and the rich tradition and history of the company have shaped its way of doing business. Since its foundation, the company has operated in the textiles and fashion industries, growing to become a market leader in silk fabrics, accessories (scarves and ties), design, and manufacturing, and gaining a good reputation as a producer of creative designs and quality products.

The company, which reached 1,200 employees at its peak in the 1990s, has always been privately held and family-owned, and has always been managed by a family member. Three generations of the Soft Silk family have led the company since its establishment, and a fourth is now a part of the company's management team. Its organisational structure has evolved over the past four decades, and has adapted to the evolution of the external context, and to technological developments and management orientations. Specifically, until the 1970s, Soft Silk was structured in a traditional function-based design, while, in the 1990s, redesign efforts lead to the adoption of a geographically-based structure.

\section{The Present State}

The economic crisis, coupled with increasing challenges in its Chinese operations, represented the main triggering event that led to the need to make drastic changes. At the end of the 2000 fiscal year, the company recorded the first significant net financial loss in its history (3 million euros). Furthermore, the number of employees has been drastically reduced since the 1990s as a consequence of changes in the business's financial situation and context: at the end of 2006, the company had 732 employees. The company was organised according to a modified function-based design, with four 
distinct departments (sales development, customer service, operations, and finance). The sales division did not focus on specific clients and businesses, but was organised according to the geography of the three markets served (Italian, French and EU-Asian). This configuration had a twofold drawback: on the one hand, the sales organisation had only limited knowledge of the company's design and manufacturing capacity; on the other, the design and manufacturing units had very limited and indirect interactions with the clients. Clear issues of overall efficiency were identified and had to be addressed under increasing external market pressures.

Even though the organisational structure had been changed over the decades, with an attempt to adapt to the external context, the same cannot be said for the family mind-set and of the manner in which reality was shaped. The family was afflicted by strong cultural inertia deriving from its success and high reputation, and displayed significant tardiness when it came to taking the initiative. In addition to a constantly worsening scenario, the company needed to solve its short-term problem situation, but most of all to re-shape its long-term orientation. To accomplish this, in 2006 the family took a drastic decision: to hire an outsider as CEO for the first time in the company's history. Although the decision to rely on an external, competent CEO might appear to be a sign of on-inertia, it can also be interpreted as a forced, unplanned disruption caused by the need to avoid bankruptcy. The new CEO immediately understood that there were several challenges to be dealt with: turning around ten years of losses, developing in-depth knowledge of products and material, managing creative people, and designing and managing the creative and the manufacturing processes. For the company to survive, the management team had to act on multiple fronts within a relatively short timeframe. First of all, the financial situation needed to be faced by means of a recovery plan (both short-and longterm). Second, the company's vision and mission had to be revised by aligning organisational design and management systems to them. Third, there was the challenge of transforming the company's 
culture and the way it did business, also by developing new processes and products without affecting the company's competitive edge, which was its creativity.

\section{The Transformation Process at Soft Silk}

December 2006 marked the moment when Soft Silk’s transformation began. It was a five-year process, complex and challenging, which involved strategy, vision, organizational structure, and, most of all, the family culture. It began with an intervention to solve the urgent bankruptcy problem in the short term. Then the foundations were progressively laid for instilling a new long-term orientation based on a professional culture, accountability, competitiveness, and customer orientation.

We will now present the case, the aim being to illustrate the central part of the framework. The phases of the framework are illustrated within the case, as follows. Each subsection will describe a single phase, highlighting the key activities, the key actors, the barriers, and the results.

Implementing radical action. The first phase was aimed at reversing the descent to bankruptcy and resolving the financial emergency, and it lasted from December 2006 to March 2007. The owner family attempted to convey the urgency of a system-wide change, and then stepped aside, in order to learn from the actions of the new $\mathrm{CEO}$ and not to interfere with them. On his first day on the job, the new CEO met the CFO, and realised that the company had two months of cash available. It had no money to pay suppliers, and its current cash reserves would provide only two to three more months of wages for the employees. The perception of the emergency within the company was scant; nobody had a sense of the impending financial disaster. An agreement with the trade union on the changes required, and the commencement of a dialogue with the banks regarding the development of a recovery plan were crucial. The first goal to be pursued was the financial survival of the company. The company's financial state required drastic measures. The challenge was how to halt the financial bleeding and at the same time preserve the company's core; in other words, how to manage the trade- 
off between the long-term orientation and the urgency of the first actions. Cash and cost-cutting became the real drivers behind management decisions in the first months of the CEO's tenure. The union leaders understood the gravity of the situation, and knew that additional unrest would probably result in major damage from which the company might not be able to recover. The message to the banks' CEOs was the same, with one additional proviso: long-term debt was to be renegotiated with the lenders, and repayments rescheduled.

After this first intervention, the financial emergency was settled, but during this initial phase the CEO had immediate experience of the most deep-rooted hindrances to the company's progress: cultural inertia and the family's and the company's resistance to changing their way of doing and seeing things.

Achieving Immediate Financial Security. The second phase began in March 2007, and lasted until the end of that year. After his initial actions, the CEO started to focus on achieving immediate security, which in this case was related to financial security, while both respecting family traditions and laying the foundations for a new way of doing business. After joining the company and analysing the situation from the inside, the CEO realized that the problems faced by the company could be ascribed to two main causes: the economic crisis in the market in general and the textile business in particular, and bad management in recent years.

Several other key actions therefore needed to be taken. The workforce was reduced, and by mid-February 2007 (two and a half months after the CEO’s arrival), the company was downsized from 732 to 550 employees, half of whom were in the four 'converter' divisions, and the rest in the production divisions. Money-losing product lines were closed, and capital expenditure and inventory were drastically reduced. A major disposal plan for non-operating assets was implemented. At this time, the CEO realized that a new financial discipline had to be introduced within the company. He consequently tried to convey the message to the management that 
"Everything you do must have a financial pay-back".

This was a shock in terms of culture. Financial discipline was achieved through two main interventions:

a) Management tools to support the restructuring and recovery process. These were based on a monthly reporting process and the implementation of divisional accounting procedures. Management was held accountable based on performance data. For the first time, the executive team had a clear understanding of where the company was making or losing money. A new information system was also implemented to support the re-engineering of the company, particularly its drive to reduce the cost of its non quality. The outcome of this was increased operating profitability in spite of declining revenues, increased revenue per head, and an improved debt-to-equity ratio. Some of the proceeds from the asset disposal were invested to upgrade plant machinery.

b) Building a new management team. Internally, a new management team was established that bought into the new vision and the importance of the development of a professional management culture. Most of the top management team (with one exception) was replaced by new managers who were promoted from inside. 'Leading by example as professional managers' became the mantra. A group of talented young managers was hired from outside, and an effort was made to build on them. This was very hard in terms of risk and the amount of work dedicated to training, but it was necessary in order to bring in new ideas, points of view, and ways to reshape the image the company had of the market environment (and the image of the firm itself). The principle of accountability was applied: 'you are responsible for what you do and you are supposed to achieve results'. The focus shifted to performance indicators such as quality measures, reliability measures, budget planning and management, development of people, and enhancing creativity. Performance and professionalism became 
the key criteria for managerial success, promotion, and retention. Managers were expected to create a professional culture in their own units by information-sharing, communication, involvement, and creating high-performing teams. Managerial practice had to be embedded in data that were collected regularly in a scientific and rigorous manner, and interpreted and acted upon. As work units began to collect, share, and interpret data, the degree of professionalism increased. This campaign also led to two more tangible major results: the company became more cost effective, and it increased its competitiveness.

The most critical barrier faced by the CEO during this phase was the lack of tools. The reporting and managerial system had not been designed at all when he joined the company.

Building a Strategy. The third phase took place between the beginning of 2008 and the beginning of 2009. The time had come to think intensively about the firm's long-term sustainability, with the advantage of having laid the foundations in the previous phases. The main hindrance was the latent cultural inertia of the company's employees and the family owners. It was clear to the CEO that the most critical problem remaining was that the company lacked a competitive approach: the attitude was 'Let's try to make products very well', but no attention was paid to profit and competitiveness. In December 2006, the company's vision and mission were:

"Weaving emotions. Soft Silk pursues a role of leadership in the silk industry and related value added services”

The mission was elegantly drafted, but was not business-oriented. It was interpreted by many in the company to mean that their job was to craft works of art, and not necessarily to make products to be sold at a profit. The message that had to be sent was clear: emotions do not pay the mortgage, and we are in the business of making money, not just crafting art or poetry. The concept of 'value chain' was introduced:

"Every part of the chain must add value to the product" 
The challenge was to reshape the views of the company and to build a new competitive strategy. Hence three main factors were emphasised: price competitiveness, to be attained by cost reductions; quality of service; and a better product offer in terms of wider variety and more rapid renewal of catalogues.

Special people were needed to achieve the third goal. They had to be quick, and most of all, they had to be creative. Enhancing creativity was thus viewed by the CEO as a key element in the company's transformation. Creativity was one of the anchors that had led to the success of the company over the previous century. Product design and development units were established within each of the four divisions. Having a product design and development capability within each division allowed for greater proximity to the client, which, in turn, enhanced creative solutions. A new VicePresident for Product Design and Development position was appointed to coordinate and enhance the overall emphasis on creativity. Lastly, the company launched a collaborative research project with researchers from the Politecnico di Milano to study the phenomenon of collective creativity and to experiment with alternative ways to design learning mechanisms that could enhance or trigger collective creativity.

This was the moment for further strategic reflection: the possibility of merging with Soft Silk's historic competitor. Located in the Como area and family-owned, this competitor operated in the same market and, like Soft Silk, was facing hard economic times due to increasing competitiveness in the sector and the global crisis. After a detailed study of how the two companies could be merged in terms of organizational structure and productivity, the operation was not concluded: the family owner of Soft Silk’s competitor would not relinquish his leading role to an outside CEO.

Despite the fact that the merger was not successfully concluded, significant results began to appear during this phase. Word of Soft Silk's transformation had begun to spread in the industry. The company was able to attract new talent, existing customers began to increase their orders, and former 
customers that had dropped the company began to discuss opening new accounts. Clients heard about the transformation efforts, and as a result overall sales began to increase. In 2009, the company went into profit after nine years of losses.

Developing the Vision. At this point, attention had to be focused on developing a shared vision for all the different levels of the company, one that gathered together the various culture and subcultures in the different units. All of 2009 was dedicated to the implementation of this phase.

A company's culture and subculture reflect the common experiences of organizational members within their working units. The critical issue was the geographically-based design of the sales force, which led to a lack of personal accountability for product design and delivery. The sales unit's assumption was that it was up to others in the company to design, manufacture and deliver the product according to the specifications in the contract. It was not the sales organization's responsibility if the product was not delivered according the expected specifications, quality, or timeframe. The assumptions that emerged from the product design department included a belief that the success of the company was based on the creativity of its products, which therefore could be completed within an unrealistically short timeframe. Conversely, the assumptions of the manufacturing organization included convictions that no-one knows production capacity better than the people in the manufacturing organization, that a sales organization has no clue about the complexity of the manufacturing process, and that unfortunately many production schedules were set without any input from manufacturing personnel. The overall model that emerged was the view that no-one saw themselves as the responsible party. Moreover, the financial losses of the previous eight years were 'normal', and the commonly-held belief was that 'someone will pay the bill'. It was clear that the company's cultural inertia was still very strong. The CEO set out to transform this culture by facilitating accountability-based practices for every member of the organization, and introducing specific technologies for intra-organizational communications and cooperation. A dialogue with 
major clients was also started in order to talk about past and present experiences and future opportunities, and to gain a clearer perception that customer satisfaction and overall sales depended directly on Soft Silk’s performance, not on 'faith'.

Redesigning. The restructuring of the company took place during 2010. The task was now to build an organizational structure that reflected the new business strategy. The 2006 company structure was driven by a sales organization that was geographically-based. The sales division would go first to the design department and then to the manufacturing unit, and also served as the main contact with the client, regardless of its size or flexibility in terms of possible product interest. The sales organization had limited knowledge of design and manufacturing capacity. It was also ignorant of the capacity to deliver ordered materials within the requested timeframe. The design and manufacturing units had very limited direct interaction with the client.

In 2010, the organizational chart was re-structured, following a hybrid 'convertor' and 'holistic' (vertically-integrated company) orientation. Four divisions were established: Women’s Wear (fabrics and accessories for luxury goods clients), Fashion (women's wear and beachwear fabrics for the fast fashion sector), Menswear accessories (fabrics and finished products), and Licenses and Distributions (the distribution of women's and men's accessories made under license agreements).

An additional administrative unit, which included Human Resources, Information Technology, Finance, and Purchasing and Procurement, was established to work in close collaboration with and to support the four divisions. Business divisions became responsible for their own sales, design and development, purchasing, and sourcing. They would source their products both internally (from the manufacturing division) and externally.

The rationale for the changes in the organization was twofold. First, product orientation, and not geography, became the key variable for the sales efforts to be effective. Customers who bought both scarves and fabrics and ties had different buyers and purchasing decision-makers, whether they 
purchased the former or the latter, and the product and sales skills required to service the menswear and women's wear segments were different. Different resources must therefore be dedicated to them. Second, accountability had not been enforced by the previous organizational structure: the sales people were blaming designers or manufacturing because they were not delivering products on time or to the customer's satisfaction; manufacturing was blaming the sales organization because they customarily oversold products that had not yet been sufficiently tested or which had delivery dates that the manufacturing could not fulfil. Under the new organization, division heads had control over the entire development, sourcing, and sales process, and were free to choose their suppliers. Management had to convert to a 'no excuse’ culture and approach.

The structure of the 'external governance’ was also changed. The structure and composition of the board of directors changed from four family members and three outsiders (who were all family friends) to three outsiders with a variety of managerial expertise and knowledge depth of the industry. The statutory audit committee that must by law audit company practices and reports (law and tax periodic assessments) was revitalized with two new highly-and members, one of whom became the head of the committee. At this point, the transformational intervention of the CEO could be considered accomplished. 
Table 2. The Transformation at Soft Silk

\section{IMPLEMENTING}

RADICAL ACTION

TIME

KEY

ACTIVITIES

PROCESSES

Renegotiation of long-
term debt

\section{Cutting costs}

Closure of money-losing product lines

Institution of

communication

mechanisms

KEY ACTORS

INVOLVED

RESULTS

Increasing availability of

cash

Avoiding bankruptcy

BARRIERS

\section{ACHIEVING \\ IMMEDIATE \\ FINANCIAL \\ SECURITY}

\section{7}

Reduction in workforce

Reporting process and accounting procedures

New information system

New top management with Politecnico di

\section{Top management}

Increased efficiency of management

Increased accountability of management

Lack of tools Milano to enhance

creativity

\section{BUILDING A}

STRATEGY

$2008-2009$

Instilling the concept of competitiveness

Establishment of product design and development units within each

division

Collaborative research

\section{Employees and top} management

Attracting new talent

Orders increased

Profit

Cultural inertia

\section{DEVELOPING A}

VISION

$2009-2010$

Transforming the

company culture

Valuing people's experience and

knowledge

Dialogue with major clients to evaluate company performance

Employees and top management

Having a shared vision through the whole company

Cultural inertia

\section{REDESIGNING}

2010

'Convertor' + 'Holistic' and marketing orientation

Additional administrative unit

\section{New Board of Directors}

New Statutory Committee of Auditors

Employees and top management

Having an organizational structure that reflects the new business strategy

Cultural inertia 
The September 2010 revised mission states:

"Soft Silk's mission is to grow with profit at the service of our customers. We endeavour to guarantee excellence and leadership in textiles and accessories, thanks to the quality of our unique and innovative creations.”

The revised mission reflects and emphasises the combined drive for profitability and highquality service to clients. It also highlights the commitment to continuous creativity, innovative design, and product quality.

It should be said that even during this phase the CEO had to work hard to overcome the cultural inertia of the company and the family, which felt very uncomfortable with the changes that were being implemented. Some of the key features of a family-owned business, such as the preference for putting family members in charge and the patterns of tradition of established behaviour, induced the family to take the decision to replace the outside CEO in any event after he had completed the transformation process. In fact, it was clear from the outset that his intervention would be 'temporary', and was considered to be an exceptional event which departed from tradition.

Table 2 provides a synopsis of the transformation process in terms of phases, key activities, results, the key actors involved, and barriers.

\section{The Future State}

The moment had come for Soft Silk to step into the future state. 2011 was the last year of the CEO's collaboration with the family firm. It was the moment when the results were harvested. The CEO was to leave the company in October, and a member of the family, who was a part of the company's executive team, was to become the new CEO. The preparations for this changeover and the consolidation of the managerial and professional culture throughout 
the company were the key elements of this transition, which might be defined as the 'blossoming'. This means that the time had come to see whether the seeds of change and innovation (in terms of strategy, vision, and structure) that the departing CEO had planted during the five-year transformation process would take root and finally blossom. During the blossoming period, the departing CEO empowered the top management team to take full ownership when he stepped aside, and to make every effort to achieve the results driven by the transformation process. He pointed out the significant goals that the company had reached, but most of all he continued to highlight what objectives Soft Silk still had to pursue. These objectives related to the maintenance and improvement of profitability, investment in the continuing development of technological assets and professional skills throughout the company, and the continued pursuit of market competitiveness - facing competitors effectively, and caring about the level of service perceived by clients. In fact, he noted the fundamental lessons that the family firm would have to learn in order to be capable to continue without the departing CEO.

The handover between the departing CEO and the new CEO, who was a family member, actually took place in October 2011. The family took charge of guiding the company once again, with a consolidated set of new competences and managerial skills. There was basically only one new goal to be accomplished: achieving positive results. This meant continuing to pursue economic growth, increasing the market share, and augmenting the company's internationalization by expanding its market presence and its chain of shops through commercial joint ventures with partners from the developing nations such as India. The departing CEO had no doubts on this point:

"[...] it is necessary to sell products in those countries in which the emerging middle class is willing to spend money". 
The economic figures are evidence of the positive results of Soft Silk. At the end of 2011, the company registered a 4\% sales growth, and was the only family-owned enterprise in the Como district to show a profit, with sales amounting to 68 million euros. There was no further significant workforce downsizing after its first reduction during the second phase of the transformation. The number of employees was about 500 after the transformation, against about 700 at the beginning.

The future state should also involve one fundamental characteristic: a 'no-inertia' culture. This means the capability to adapt to the external context and to be flexible in the way of shaping reality, in order to be able to achieve positive results even when the context changes, and to avoid the 'inertia effect' of success. As the CEO who implemented the transformation pointed out:

"The firm is now able to understand quickly what is happening and to adapt itself: the capability to change is the key success factor."

This section has described and analysed the case of an Italian family business in the fashion design sector, and illustrated utilization of the proposed integrative transformation framework. The case was organized and examined by using the key elements and dimension of the proposed framework. In the next section, the framework will be further discussed, using elements from the case illustrated above, in order to explore its potential added value and identify the implications for practice and future research.

\section{Discussion}

This paper has addressed an aspect which has been considered lacking in the management literature: that is, a holistically-based strategic approach to organizational transformation in a family business (Boyle and Desai, 1991; Chowdhury and Lang, 1993; Miller 
and Le Breton-Miller, 2005). This requires that three relevant elements from different business fields be combined (Cater and Schwab, 2008): namely:

(i) organizational theory and design, particularly the sub-field that focuses on the key organizational characteristics of family business

(ii) organizational development and change, particularly the sub-field that studies transformation

(iii) organizational behaviour, particularly the sub-field of transformational leadership.

The paper has presented an illustrative case study and utilized the proposed guiding framework to examine the transformation of a family-owned firm.

The case illustrated demonstrates that, when addressing transformation, family firms must deal with complex and specific problems related to their traditions and industry (Habbershon, Williams, and MacMillan, 2003; Sharma, Chrisman, and Chua, 1996); at the same time, the case allows us to point out some of the merits of the proposed guiding framework in relation to clearing these specific hurdles. Accordingly, the discussion focuses on these two topics respectively, presenting the evidence that confirms how problematic transformation is in family businesses (Dunn, 1996; Stoy Hayward, 1993; Donckels and Frolich, 1991; Dyer, 1986), and discussing how the framework can help these organizations manage transformation.

\section{Challenges in the Transformation of Family-Owned Businesses}

As we have shown in our theoretical background, transformation is a crucial issue for the survival of most companies, regardless of their ownership characteristics and size, and it is today considered to be one of the most critical managerial challenges. In the case of family businesses, transformation is considered even more critical for success, and appears to be more 
challenging and risky. From this perspective, the illustrative case confirms that certain key features of family businesses tend to limit their ability to initiate and effectively manage transformation. In particular, we found at least five specific features that make it difficult to trigger, design, and manage the transformation process.

The strong ties of the top family managers both to the family business and to the other family members (Chua, Chrisman, and Steier, 2003), combined with the visibility and reputation of the family (Dunn, 1996) in a context such as the one in which the company was placed, made commencement of the transformation problematic. Nevertheless, some of the literature suggests that family firm characteristics may be turned into facilitators of change (Salvato et al., 2010). In our case, the transformation was initiated after more than ten years of losses, when the company was close to bankruptcy. Moreover, the link between business and family entails difficulties not only in setting change in motion but also in managing it. Transformational leadership capabilities seem to be fundamental for the effectiveness of change management during the transformation process. The illustrative case shows the effectiveness of distributed leadership between the outsider CEO and the family, collaborating through a close professional relationship with the aim of sharing the new vision among all the people in the organization.

Second, the typical preference for placing family members in charge (Howorth and Ali, 2001; Lansberg, 1988; Morris, Williams, Allen and Avila, 1997) limits the pool of potential candidates, and has a negative impact on the effectiveness of a transformation. In our case, the family decided to engage a non-family executive, thereby fostering the need for a new top management team. This was one of the issues that the CEO managed during the second phase of the transformation. In particular, by promoting people from inside and hiring young talent from the market, the CEO 'set new rules': as a requirements for a career, family affiliation which is a key feature of family business - should be coupled with professional competences 
and potential. In this way, past-anchored orientation was turned into future-focused impetus. The replacement of the top management is seen as a pre-eminent option for making rapid changes in family firms, especially when a crisis is under way and urgent actions are needed. This illustrates how the role of the family, as a launcher or initiator of change, should be disengaged from that of the outside expert, who actually carries out business discontinuity and facilitates rapid and effective changes (Salvato et al., 2010).

The consensus orientation and the tendency toward conflict avoidance in the management style (Priem, 1990; Dess, 1987; Amason, 1996) represent a barrier to transformation, as they absorb many managerial resources of a magnitude that depends on the specific succession and context patterns (Miller et al., 2003). In our case, those issues prevented any swift response to the organizational threats and forced the external CEO to replace the entire managerial team and to spend time and energy on establishing 'a culture of accountability'. He therefore implemented divisional accounting procedures and specific information systems in order to constantly monitor the profitability of all the organizational units and sub-units. The informal nature of the relationship between the family members that managed the company seems to have served as a roadblock in the establishment of a professional management culture (Morris et al., 1997), and of the establishment of a management control systems in particular (Donckels and Frohlick, 1991).

Furthermore, the internal focus of the family (MacKenzie, 2002; Jensen, 2003) had a negative impact on triggering the necessary transformation because it made it harder to focus on external markets. That is the reason why the management team redesigned the company in order to have four divisions responsible for their own markets. In conclusion, having highlighted the key features of family businesses that hinder transformation (strong family ties, a small pool of professional managers, an emerging informal family-based management culture, consensus orientation, informal control management systems, and internal orientation), we 
argue that transformation of family businesses and the overcoming of their typical inertia, is an important area of inquiry that should be at the core of family business research.

\section{The merits of the proposed guiding framework}

The discussion now moves to analysis of the guiding framework for managing transformation, presenting its merits in dealing with the typical obstacles encountered by companies when transforming the organization. In particular, the focus is on four features of the framework that seem important in overcoming those obstacles.

The first concerns the very first phase of the framework, which is the triggering event. Considering the difficulty of initiating the process, this event can be considered a necessary requirement for the transformation of family businesses. Indeed, the trigger event simultaneously:

(i) enhances critical reflection on current thinking, practices and routines

(ii) dynamically creates awareness of change within the complex social arena that characterizes family businesses.

The event thus forces the company to acquire the sense of urgency that readies it for transformation, and to seek - both internally and externally - the capabilities needed by the transformation. In companies of other kinds, both change readiness and the change capabilities can be activated by diverse processes: for example, top management initiatives, internal political pressures, or suggestions from external consultants. The inertia of family-owned businesses requires a marker event (Poza, 2008) which the members of the social system that constitutes a family business consider a symbol representing a need for transformation.

The second merit of the proposed framework lies in its cross-activities. Indeed, the models typically proposed by the previous literature on transformation (as in Greiner et al.'s 
model presented above) are structured as sequential processes that seem to underestimate the inertia of family business, that are requested to deal with the resistances to change. For example, Greiner et al.'s model comprises an initial negotiating phase in which the CEO arranges a mandate to change, or there is a specific phase in which the change effort moves to commitment creation aimed at releasing and mobilizing employee energy. In the case of family-owned businesses, those actions must be seen as transversal because negotiation between the family and external top management and the overcoming of resistance to change are present in all the phases of the transformation. Accordingly, in the case considered, the relation with top family members on the one hand, and employee involvement and participation in the process on the other, were permanent features of a process that by design assumed inertia as a constitutive element of family businesses.

The third advantage of the framework is the 'blossoming' of the future state. In fact, given the long-term orientation that characterizes family businesses, a transformational process cannot be considered concluded when it reaches the future state and the expected operational results. Indeed, the transformation not only impacts on the company and its figures but it explicitly or implicitly affects the family and the balance among its members. Hence, effective transformation fixes one or more problems but also contributes to shaping the future and to creating a shared vision among family members. In fact, current family managers typically perceive the organization as a legacy from past generations to be handed on to future generations (Covin, 1994; Barach and Ganitsky, 1995; Handler, 1994; Sharma et al., 2003; Dunn 1996; Stoy Hayward, 1992, 1993; Stein, 1989, 1988).

The final advantage of the proposed framework is its focus on transformational leadership and organizational change capabilities. The literature on the process of creating and sustaining successful organizational change programmes (e.g. Kotter, 1996; Lahteenmaki et al., 2001) shows the importance of a set of specific organizational competences called 'change 
capabilities'. This expression denotes the ability of an organization efficiently to plan, design, and implement all types of change with committed stakeholders, causing minimal negative impacts on people and operations, so that desired business and cultural results from change are consistently achieved and integrated seamlessly into operations to deliver maximum ROI (Anderson and Anderson, 2001). Part of organizational change capability is the design and utilization of learning mechanisms - understood as planned proactive features that enable and encourage organizational learning (Shani and Docherty, 2003). Organizational learning mechanisms are crucial because if they are purposefully designed, they can support the acceleration of organizational transformation and the development of new capabilities (Fredberg et al., 2011). From this perspective, the framework underlines the importance of the creation and the capitalization of change capabilities. Organizational change capabilities are linked to the top management and formal and informal leaders. Thus transformational leadership is, again, a key element. The framework illustrates several phases in which the leader is supposed to implement some of the typical assumptions of transformational leadership. In the case presented, for example, Intellectual Simulation was enhanced by the creation of a new management team, both by promoting people from the organization and by hiring talented new people from outside. This new managerial group acted as a bottom-up change agent and facilitator of new ways to frame problems and be creative and innovative.

In conclusion, the framework proposed for the management of transformation in family businesses seems to have features (i.e., the need for a trigger event, the presence of transversal activities rather than a totally sequential approach, and the importance of a longterm orientation) that may help overcome the typical transformation barriers in family firms presented above.

\section{Conclusions}


The paper has proposed a framework for managing transformation in family businesses, and a case study that illustrates it. It has assumed that transformation in family-owned business has distinct features and requires a comprehensive guiding roadmap and a process (Poza 2007, 2008; Dunn, 1996; Stoy Hayward, 1989, 1990, 1992; Donckels and Frolich, 1991; Welsch, 1991; Dyer, 1986). Transformation is affected by specific characteristics of family firms, such as strong ties to the business, an emerging informal family-based management culture, consensus orientation, internal orientation, and long-term goal perspectives. Those key features represent both obstacles and resources for transformation that should be considered when designing and leading the process. From this perspective, we have contributed to both management practice and research.

From the practice point of view, the paper has provided a guiding scheme and a set of specific recommendations that might help family-owned business managers in designing and managing transformations. The proposed framework highlights the importance of addressing the relationships and dynamics that result from the family members' involvement as both owners and members of the organization. The case study has illustrated one approach taken by a family to hire an external CEO with the appropriate knowledge base and competences needed to manage business transformation, also as a way to turn past-orientation into future-focused impetus. Other approaches should be examined by family owners and specific criteria established in order to make the most appropriate choice for a family-owned business. Once the choice has been made, and the CEO chosen, the Chairman of the Board, who in most cases is a member of the family, must empower the CEO and support his or her actions. This support is critical, especially in the context of designing and leading a system-wide transformation that in many cases may run counter to the way of doing business that has evolved over many years of business practice and family traditions. 
The proposed framework also points up the need for a long-term orientation in a complex transformation process. Changing a company culture is not a quick fix (Schein, 2006). Persuading family members to buy into and commit to a ' new way' is never easy. A key element in transformation is adopting the view that it is an ongoing process that occurs naturally in any living system (Bartunek and Louis, 1996), but one that has to be designed and managed as an integral part of organizational routines. As long as long-term orientation is a specific characteristic of family businesses, effective transformations need to be perceived as a continuation of the work done by past generations, and as preparation for the work to be done by future generations. In other words, transformation needs to be perceived as something that the company founders would have done, not as the pursuit of transient managerial fads. Like the two mentioned above, this paper proposes a set of recommendations that might provide support for decision-makers in family businesses in initiating and effectively managing transformations, and help evaluate which the effective actions might be, and what are the consistent characteristics of a transformational leader (in this case the hired external CEO).

This paper also highlights the need for further scientific research in certain areas. It has extended the existing literature, which has not focused fully on transformation in family-owned businesses, by integrating two bodies of scientific knowledge: family business, and organizational change and development. This integration requires further study and theoretical development. Studies that examine the relevance and applicability of the proposed framework in diverse industries and locations would provide insights leading to a more generalizable framework. Furthermore, because the illustrative case is based on a successful transformation, an experimental application of the framework to failed transformation(s) would increase its reliability and robustness. The nature of a transformation is often related to turnarounds, especially in the global economic crisis, and particularly for family businesses. An exploration 
of the relationship between transformations and turnarounds in family-owned businesses would be of added value (see, for example, Cater and Schwab, 2008).

Leaders are responsible for designing and leading system-wide transformations. As such, a specific set of studies that investigated the effect of a type of leadership structure (that is, focused, collective or distributed) on the transformation process and outcomes, the possible effects of a transformational leadership style on transformation effectiveness, and the effect of leadership dynamics on overcoming resistance to transformation, would be critical for an understanding of the design and management of system transformation (Ford and Ford, 2012). The study also points up the possible relationship between transformation and strategic innovation (Govindarajan and Trimble, 2005, 2011) in family-owned businesses. Strategic innovation can serve as a trigger for, and may possibly nurture, the transformation process. Empirical research into this possible relationship is likely to generate new understanding. Similarly, technological innovation can serve as a trigger for transformation or as a transformation lever, yet little scientific knowledge can be found to support such notions within the context of family-owned businesses and considering family involvement (De Massis et al., 2012).

At the core of the transformation process lie learning and learning mechanisms without which progress is likely to be limited, and yet no scientific knowledge can be identified that explores the possible relationship between learning and transformation, nor is there any knowledge specific learning mechanisms or the tapestry of learning mechanisms that might be designed and managed in order to enhance the transformation process and outcomes. Finally, this paper makes a specific contribution in terms of the knowledge-creation processes (McLean et al., 2002) through which family business issues can be addressed. In particular, the case have presented is the result of a long-term research process based on a collaboration between academia and a specific company (Shani et al., 2012) that has specific merits in terms of its 
rigour, relevance, and reflection (Pasmore et al., 2008). In conclusion, we would argue that by using collaborative research methodologies to investigate the topics presented above, management research is likely to be able to address the critical emerging challenges and to contribute to the advancement of family business theory and practice. 


\section{References}

Ackerman, L., (1986). Development, transition or transformation: The question of change in organizations. Organization Development Practitioner, 18, 1, 1-8.

Ackoff , R. L., (1981). Creating the corporate future : plan or be planned. John Wiley and Sons, New York.

Amason, A.C., (1996).Distinguishing the effects of functional and dysfunctional conflict on strategic decision making. Academy of Management Journal, 39, 1, 123-149.

Anderson, D., Anderson, L.A., (2001). Beyond Change Management, Jossey-Bass.

Argyris, C., Schon, D., (1996). Organizational Learning. Addison-Wesley, Reading, MA.

Avolio, B.J., Bass, B.M., \& Jung, D.I., (1999), Re-examining the components of transformational and transactional leadership, Journal of Occupational and Organizational Psychology, 72, 441-462.

Barach, J. A., \& Ganitsky, J. B., (1995). Successful succession in family business. Family Business Review, 8(2), 131-155.

Bartunek, J. M., \& Louis, M. R. (1996). Insider/outsider team research. Sage, Thousand Oaks, CA.

Bartunek, J. M., \& Louis, M. R., (1988). The interplay of organization development and organizational transformation. In Woodman, R. W. and Pasmore, W. A. (Eds), Research in Organizational Change and Development, Vol. 2, 97-134, JAI Press, Greenwich, CT.

Bass M.B., \& Riggio, E.R., (2006). Transformational Leadership, London, Lawrence Erlbaum Associates Publishers

Bass, B.M., (1998) Transformational Leadership. Lawrence Erlbaum, Mahwah, NJ.

Bass, B.M., \& Avolio, B.J., (1990). The implications of transactional and transformational leadership for individual, team and organizational development. Research in Organization Change and Development, pp. 231272, in Woodman, R.W. and Pasmore, W.A. (Eds), JAI, Greenwich, CT.

Battilana, J., Gilmartin., M., Sengul, M., Pache, A., \& Alexander, J. A., (2010) Leadership competencies for planned organizational change. Leadership Quarterly, 21, 422-38.

Beckhard, R., (2006). What is organization development? Organization Development, 3-12, in Gallos, J.V. (Ed.), Jossey-Bass, San Francisco, CA.

Beckhard, R., and Pritchard, W., (1992). Changing the essence: the art of creating and leading fundamental change in organizations. Jossey-Bass, San Francisco, CA.

Beer, M. (2009), High commitment, high performance: How to build a resilient organization for sustained advantage. Jossey-Bass, San Francisco, CA. 
Beer, M., (2011). Making a difference and contributing useful knowledge: Principles derived from life as a scholarpractitioner. In Mohrman, S. A., \& Lawler, E. E. (Eds), Useful research: Advancing theory and practice. BerrettKoehler.

Bennis, W., \& Nanus, B., (1985) Leaders. Harper and Rowe.

Birley, S., (2002). Attitudes of owner-managers' children towards family and business issues. Entrepreneurship Theory and Practice, 26, 1, 5-19.

Boud, D., Cressey, P. \& Docherty, P. (Eds.), (2006). Productive Reflections at Work: Learning for Changing Organization. Routledge, London.

Boyle, R.D., \& Desai, H.B. (1991). Turnaround strategies for small firms. Journal of Small Business Management, 29, 3, 33-42.

Bradford, D. L., \& Burke, W. W., (2005). Reinventing Organization Development: New Approaches to Change in Organizations. Pfeiffer, San Francisco, CA.

Carney, M., \& Gedajlovic, E., (2003). Strategic Innovation and the Administrative Heritage of East Asian Family Business Groups. Asia Pacific Journal of Management, 20, 5 - 26.

Cassia, L., De Massis, A., \& Pizzurno, E. (2012). Strategic innovation and new product development in family firms: An empirically grounded theoretical framework. International Journal of Entrepreneurial Behaviour \& Research,18, 2, $198-232$.

Cater III, J., \& Schwab, A., (2008). Turnaround Strategies in Established Small Family Firms. Family Business Review, 11, 1, 31-50.

Chowdhury, S. D., \& Lang, J. R. (1993). Crisis, decline, and turnaround: A test of competing hypotheses for shortterm performance improvement in small firms. Journal of Small Business Management, 31, 4, 8-17.

Chua, J. H., Chrisman, J. J., \& Steier, L. P. (2003). Extending the theoretical horizons of family business research. Entrepreneurship Theory and Practice, 27,4, 331-338.

Cirella S. \& Shani A.B. (R.) (2012). Collective Creativity-By-Design: Learning from an Italian Fashion Design Company. Irish Journal of Management, 32, 1, 53-76.

Cirella, S., Guerci, M., \& Shani, A.B. (2012). A Process Model of Collaborative Management Research: The Study of Collective Creativity in the Luxury Industry. Systemic Practice and Action Research 25, 3, 281-300.

Collins, J., \& Hansen, M. T. (2011). Great by Choice: Uncertainty, Chaos, and Luck--Why Some Thrive Despite Them All. HarperCollins, New York, NY.

Collins, J., (2001). Good to Great: Why Some Companies Make the Leap and Others Don’t. HarperCollins, New York, NY. 
Covin, T. J., (1994). Perceptions of family-owned firms: The impact of gender and educational level. Journal of Small Business Management, 32, 3, 29-39.

De Massis, A., Frattini, F. and Lichtenthaler, U. (2012) 'Research on technological innovation in family firms: present debates and future directions’, Family Business Review, 26, 1, 10-31.

Dess, G., (1987). Consensus on strategy formulation and organizational performance: Competitors in a fragmented industry. Strategic Management Journal, 8,259-277.

Donckels, R., \& Frolich, E., (1991). Are family businesses really different?. Family Business Review, 4, 2, 14960.

Dunn, B., (1996). Family enterprises in the UK: a special sector?. Family Business Review, 9, 2, 139-55.

Dyer, W.G. Jr., (1986). Cultural change in family firms: Anticipating and managing business and family transitions. Jossey-Bass, San Francisco, CA.

Dyer, W.G. Jr., (2003). The family: the missing variable in organizational research. Entrepreneurship Theory and Practice, Vol. 27 No. 4, pp. 401-16.

Filbeck, G. \& Smith, L.L., (1997). Team building and conflict management strategies for family businesses. Family Business Review, 10, 4, 339-52.

Ford, J. D., \& Ford, L. W., (2012). The leadership of organization change: a view from recent empirical evidence. Research in Organizational Change Development, 20, 1-35.

Fredberg, T., Norrgren, F., \& Shani, A. B., (2011). Developing and sustaining change capability via learning mechanisms: a longitudinal perspective on transformation. Research in Organizational Change and Development, $19,117-161$.

French, W., Zawacki, R. \& Bell, C. (Eds.) (2005). Organizational Development and Transformation: Managing Effective Change, p. 10. McGraw-Hill/Irwin, Burr Ridge, IL.

Galbraith, J. R. (2002). Designing Organizations: An Executive Guide to Strategy, Structure, and Process. JosseyBass, San Francisco, CA.

Gallos, J.V., (2006). Organization Development. Jossey-Bass, San Francisco, CA.

Gersick, K. E., Davis, J. A., Hampton, M.M., \& Lansberg, I. (1997). Generation to generation: Life cycles of the family business. Harvard Business School Press, Boston, MA.

Gilodi, C. (2011). La risposta dell'industria tessile comasca alla recessione mondiale. Osservatorio Distretto Tessile di Como, Centro Tessile Serico di Como

Govindarajan, V., \& Trimble, C., (2005). 10 Rules for Strategic Innovators: From Ideas to Execution. Harvard University Press, Boston, MA. 
Govindarajan, V., \& Trimble, C., (2011). The CEO’s role in business model reinvention. Harvard Business Review, 89, 1, 2011.

Greiner, L., Cummings, T., \& Bhambri, A., (2003). When New CEOs Succeed and Fail: 4-D Theory of Strategic Transformation. Organizational Dynamics, 32, 1, 1-16.

Gronn, P., (2002). Distributed Leadership as a unit of analysis. Leadership Quarterly, 13, 423-51.

Habbershon, T. G., Williams, M. L., \& MacMillan, I. C. (2003). A unified systems perspective of family firm performance. Journal of Business Venturing, 18, 451- 465.

Hall A. , Melin L., \& Nordqvist. (2001). Entrepreneurship as radical change in the family business: Exploring the role of cultural patterns. Family Business Review, 14, 3.

Handler, W. C. (1994). Succession in family business: A review of the research. Family Business Review, 7, 2, 133-157.

Howorth, C.,\& Ali, Z.A. (2001). Family business succession in Portugal: An examination of case studies in the furniture industry. Family Business Review, 14, 3, 231-244.

Jensen, R. (2003). Tradition is double-edged sword in family business. Journal of Corporate Renewal, 16, 6, 8$10,24$.

Jick, T.D., (1992). Managing Change. Irwin, Burr Ridge, IL.

Kotter, J. (1996), Leading Change, Harvard Business School Press.

Kotter., J. (1995) Leading change: why transformational efforts fail. Harvard Business Review, 73, 2, 59-67.

Lahteenmaki, S., Toivonoen, J., Mattila, M. (2001). Critical aspects of organizational learning research, British Journal of Management, 12, 113-129.

Lansberg, I. (1988). The succession conspiracy. In C. E. Aronoff, J. H. Astrachan, \& J. L. Ward (Eds.), Family business sourcebook II (pp. 70-86). Business Owner Resources, Marietta, GA.

Le Breton-Miller, I. \& Miller D. (2006). Why do some family businesses out-compete? Governance, long-term orientations, and sustainable capability. Entrepreneurship: Theory and Practice, 30, 6, 731-746

MacKenzie, J. E. (2002). Downsizing family businesses: Family dynamics increase challenges. Journal of Corporate Renewal, 15(5), 18-21.

McLean, D., MacIntosh, R. , \& Grant, S., (2002). Mode 2 management research. British Journal of Management, 13, 3, 189-207.

Miller D., Steier L., \& Le Breton-Miller I. (2003) Lost in time: Intergenerational succession, change and failure in family business. Journal of Business Venturing, 18, 513-531.

Miller, D., \& Le Breton-Miller, I. (2005). Managing for the long-run: Lessons in competitive advantage from great family businesses. Harvard Business, School Press, Boston, MA. 
Mitki, Y., Shani A. B., and Stjernberg, T. (2008). Leadership, Development and Learning Mechanisms: System Transformation as a Balancing Act. Leadership and Organization Development Journal, 29, 1, 68 - 84.

Morris, H.M., Williams, R. O., Allen, J. A., \& Avila, R. A., (1997). Correlates of success in family business transitions. Journal of Business Venturing, 12, 385-401.

Nadler, D., (1998) Champions of Change. Jossey-Bass, San Francisco, CA.

Pasmore, W.A., Woodman, R.W., \& Simmons, A.L., (2008). Toward a more rigorous, reflective, and relevant science of collaborative management research. In: Shani AB, Mohrman, S., Pasmore, W.A., Stymne, B., Adler, N. (Eds), Handbook of Collaborative Management Research. SAGE, Thousand Oaks, CA.

Pinto, M, \& Couto-de-Souza, C. L., (2009). Organizational change in a Brazilian family business. Revista de Administracao Publica, 43, 3.

Poza, E. J., (2007). Family business ( $2^{\text {nd }}$ ed.). Thomson/South-Western, Mason, OH.

Poza, E. J., (2008). Organization Development in Family-Owned and Family - Controlled Companies. In Cummings, T. G. (Ed), Handbook of Organization Development, Sage Publication.

Poza, E., Johnson, S. and Alfred, T., (1998). Changing the family business through action research. Family Business Review, Vol. 11 No. 4, pp. 311-23.

Priem, R. L. (1990). Top management team group factors, consensus, and firm performance. Strategic Management Journal, 11, 6, 469-478.

Salvato C., Chirico F. \& Sharma P., (2010). A farewell to the business: championing exit and continuity in entrepreneurial family firms. Entrepreneurship \& Regional Development 22, 321-348.

Schein, E. H., (2006). From Brainwashing to Organizational Therapy: A Conceptual and Empirical Journey in Search of 'Systemic' Health and a General Model of Change Dynamics. A Drama in Five Acts. Organization Studies, 27, 2, 287-301.

Schultz, W. S., Lubatkin, M. H., \& Dino, R. N., (2003). Toward a theory of agency and altruism in family firms. Journal of Business Venturing, 18, 473- 490.

Schulze, W.S., Lubatkin, M.H., Dino, R.N. and Buchholtz, A.K., (2001). Agency relationships in family firms: theory and evidence. Organization Science, 12, 2, 99-116.

Senge, P., (1999). It's the Learning: the Real Lesson of the Quality Movement. Journal for Quality \& Participation, 22, 6, 34-40.

Shani, A. B., \& Docherty, P. (2003). Learning by design: Building sustainable organizations. Blackwell Publications, Cornwall, UK.

Shani, A. B., Coghland, D., and Cirella, S., (2012). Action research and collaborative management research: More than meets the eye?. International Journal of Action Research, 8, 1, 45-67. 
Shani, A.B., \& Stjernberg, T. (1995), The integration of change in organization: alternative learning and transformation mechanisms, in Pasmore, W.A. and Woodman, R.W. (Eds), Research in Organizational Change and Development, Vol. 8. JAI Press, Greenwich, CT, pp. 77-121.

Sharma, P., Chrisman, J. J., \& Chua, J. H., (2003). Succession planning as planned behaviour: Some empirical results. Family Business Review, 16, 1, 1-16.

Sharma, P., Chrisman, J. J.,\& Chua, J. H., (1996). A review and annotated bibliography of family business studies. Kluwer Academic Publishers, Boston, MA.

Stein, J., (1988). Takeover threats and managerial myopia. Journal of Political Economy, 96, 1, 61-80.

Stein, J., (1989). Efficient capital markets, inefficient firms: a model of myopic corporate behaviour. Quarterly Journal of Economics, 104, 4, 655-69.

Stoy Hayward, (1989). Staying the Course. Survival Characteristics of the Family Owned Business. Stoy Hayward, London.

Stoy Hayward, (1990). Managing the Family Business in the UK. Stoy Hayward, London

Stoy Hayward, (1992). The Stoy Hayward/BBC Family Business Index. Stoy Hayward, London.

Stoy Hayward, (1993). Index update. Family Business Magazine, 2.

Verganti, R., (1999). Planned flexibility: Linking anticipation and reaction in product development projects. Journal of Product Innovation Management, 16, 4, 363-376.

Welsch, J., (1991). Family enterprises in the United Kingdom, the Federal Republic of Germany. and Spain: a transactional comparison. Family Business Review, 4, 2, pp. 191-203.

Yin, R. K., (1989). Case Study Research: Design and Methods. Sage.

Yukl, G., (1994). Leadership in Organizations. Prentice-Hall, Englewood Cliffs, NJ.

Zahra, S. A., (2003). International expansion of U.S. manufacturing family businesses: The effect of ownership and involvement. Journal of Business Venturing, 18, 495-512.

Zellweger, T., (2007). Time horizon, cost of equity capital, and generic investment strategies of firms. Family Business Review, 20, 1, pp. 1-15.

Zimmerman, F., (1989). Managing a successful turnaround. Long Range Planning, 22, 3, 105-124. 